\title{
TRENDS IN THE MIGRATION OF THE HEALTH LABOR FORCE IN THE SLOVAK REPUBLIC ABROAD
}

\author{
Simona Hyžová \\ Alexander Dubček University of Trenčin
}

\begin{abstract}
The current situation in the countries is monitored by various experts from various fields. Various factors are monitored in the countries, including demographic developments. The change in the structure of the population, which is reflected in the aging of the population, is an irreversible process in the European Union. It is important that Slovakia, as a member of the European Union, prepares the labor market for an aging population. The aging of the population is associated in the future with the additional need for labor in many areas, but especially in health care. Among the demographic factor, which has recently resonated more and more in the professional public, is the issue of labor migration. Labor migration is one of the issues that has recently received increasing attention from the professional public, mainly due to the current demographic situation in most countries of the world. Migration is generally perceived as a natural and in many respects positive phenomenon, but it is important to investigate and monitor it in order to maintain its positive impact on society and eliminate possible adverse effects. Globalization, greater economic integration of countries, the development of technology and transport infrastructure, or the removal of political barriers, but also other factors such as changes in demographic trends undoubtedly contribute to the expansion of migration in recent periods. Although it can be of potential benefit to migrants themselves and to both countries concerned, it is also necessary to examine its negative effects and look for ways to eliminate them. Migratory flows of the labor force, especially for work abroad, its intensity and extent are not negligible indicators that affect the labor force in the health sector. Therefore, the aim of the present study is to analyze trends in labor migration as a whole in the Slovak Republic, identify the share of medical staff emigrating from the Slovak Republic abroad and identify whether the migration of health workers will affect the decline in health care in the Slovak Republic.

KEY WORDS: migration; emigration; labor force; healthcare.
\end{abstract}

\section{Introduction}

Migration is not a phenomenon today, although in recent years it has been talked about more often than in the past. As the economic, social and demographic situation on the labor market evolves, so does migration. In the Slovak Republic, experts and researchers are increasingly addressing the issue of migration, mainly due to changing demographic indicators in the labor market. Another trigger for the solution of migration was the accession of the Slovak Republic to the European Union in May 2004, which allowed the free movement of persons and the free movement of labor. Last, but not least, it was also in the context of the global refugee crisis, which has recently affected almost all the countries of the European Union. Migration should be talked about on a large scale and globally, not only in countries that have been and are significantly affected by migration and have a problem with it.

The demographic phenomenon that we encounter in almost all EU countries is an aging population. As the population in countries ages and aging is associated with a higher need for health care (Lisenkova, Mérette a Wright, 2013, Silva, et. al., 2016, Jakovljević, 2017, Colombier, 2018,). The problem of emigration of health care facilities can be a major problem for individual countries. Slovakia, as a member of the European Union, should prepare the labor market for an aging population, associated in the future with the additional need for labor in the health sector.
The aim of the present study is to analyze trends in labor migration as a whole in the Slovak Republic, identify the share of medical staff emigrating from the Slovak Republic abroad and identify whether the migration of health workers will affect the decline in health care in the Slovak Republic.

The subject of the study is the labor market of the Slovak Republic and the object of the research is labor migration of the labor force in the health sector.

We have devoted the following part of this publication to a theoretical definition of the findings so far through a systematic analysis of scientific and professional work. Theoretical overview and literature review serve in every scientific work as a mainstay for the fulfillment of the set goal.

To meet the set goal, we set a research question, which reads: "Will the changing number of emigrants in the health sector from the Slovak Republic affect the number of people employed in the health sector in the Slovak Republic?"

To verify the previous assumption, we use statistical methods that are usually used to examine the dependence of variables - regression and correlation analysis. We will monitor migratory flows from 2010, including the years that include the refugee crisis in Europe.

Regression and correlation analysis are used for mathematical description and knowledge of statistical dependence between quantitative statistical features. We describe this as a case where a unit change in one variable causes a change in the other variable (Palkovič, 2014). Thus, using this method, it is determined whether there is 
a dependence between the individual variables dependent $Z$ and independent $Y$. The result of regression and correlation analysis is a correlation coefficient, which takes values in the range from -1 to +1 . Different authors report identifying the value of the correlation coefficient at different intervals. We are based from the author Hanák (2016), who identified the interval of the correlation coefficient so that if the value is in the range from 0.8 to 1.0 , then it is a strong correlation dependence, if it is in the range from 0.4 to 0.79 so it is a moderately strong correlation dependence and if from 0 to 0.39 it is a weak correlation dependence .

The data used in the study of this issue were drawn from the Statistical Office of the Slovak Republic (SOSR) and data on labor emigration from the Slovak Republic were also supplemented from quarterly statistical documents on the Labor Force Survey. We have collected these data for each quarter and the data reported in our study are averaged for that year.

\section{Literature Review}

Authors from different countries and from several areas of research have long been dealing with foreign migration. The areas of research are different and over time they gradually change in connection with changing cultural, social, economic, or political changes in society. International migration over the last half century has significantly affected individual states in Europe (Lanari, Bussini and Minelli, 2018). This is also confirmed by Triandafyllida (2018), who claims that migration has intensified and diversified over the last 25 years.

As we mentioned in the introduction to this article, labor migration is linked to the labor market and demography. The labor market is a space in which there is an interaction between employers - their demand for work, and employees - their labor supply. (Rievajová, Pongrácz, Klimko, 2016). The situation on the labor market is influenced by several factors, such as the qualification of the labor force, social aspects and relations between employees, economic development, demographic changes, political decisions, employment legislation, etc. (Vojtovič, 2013; Startiene, Remeikiene, 2009; Krajňáková, Vojtovič, 2017; Navickas \& Kontautiene, 2013). Vojtovič (2013) says that there is a specific factor on the labor market in the Slovak Republic - the migration of the workforce abroad. The Slovak Republic is a country that is becoming interesting for immigrants from other countries, but on the other hand it is a country from which the population leaves for work abroad (Divinský, 2009; Tupá, 2016). In our study, we will focus on one aspect of migration, namely the emigration of the health workforce.

The migration of health professionals is evolving in line with trends in international migration (Tupá, 2019). Healthcare migration is not new: nurses and doctors have sought employment abroad for many reasons, including high unemployment in the healthcare labor market in their home country. In recent years, the migration of health professionals has become a more significant and controversial feature of the analysis of the health sector. It can be said that more developed countries take the workforce from the poorest countries in the world (Bach, 2003).

This is confirmed by Wojczewski et al (2015), who argue that the unequal distribution of health workers contributes to the malfunctioning of health services in many low-income countries, while several high- and middle-income countries benefit from the migration of skilled health workers. Other authors, such as Kane (2012), also point out certain benefits that a country can derive from emigrating workers. He argues that migrant health workers generally belong to the mobile middle class with a high level of education and have more economic and social resources than low-skilled migrants, who often have a difficult residence status in the destination country and are less mobile. This increased mobility can enable migrants to stay in touch with their countries of origin. Therefore, the activities of migrant health workers in support of their countries of origin can be remarkably diverse.

Already with the mention of the stagnation of the population, the future greater need for labor is expected, especially in the field of health care, with a connection to the current global shortage of health workers, Slovakia's security may be in danger. The previous statement is also confirmed by Dobriansky, Suzman, Hodes (2007) who claim that high unemployment, outflow of labor due to population aging or migration causes cracks and a shortage of workers in the labor market. There are concerns that caring for a growing aging population that is ill and dependent on support will not be possible (Jayawardana, Cylus, Mossialos, 2019).

Although there are already analyzes of the shortage of health professionals worldwide (Bradby, 2014), in the Slovak Republic this issue has only begun to be addressed recently. According to Tupá (2020), the shortage of workers in the healthcare sector has farreaching consequences, it draws attention to the daily encounters of people looking for either general or specialized doctors.

Therefore, the aim of our paper is to identify trends in employment in the health sector from Slovakia abroad within the analysis of labor emigration as a whole. Also, based on the previous analysis, identify the possible impact of emigration of health workers on the number of employees in the health sector in Slovakia.

\section{Research results}

In order to meet the set goal, it is necessary to analyze labor emigration from the Slovak Republic as a whole. From the Slovak Republic over a period of 10 years, the number of emigrants for work had a fluctuating character. The highest number of emigrants for work was in 2016 when more than 159,000 inhabitants emigrated from work in the Slovak Republic.

The smallest number of emigrants was in 2011, when 116 thousand workers emigrated. More men than women emigrate from the Slovak Republic, the share of emigrating men in the observed period was around $67 \%$ and the share of women $33 \%$. While at the beginning of the period under review the Czech Republic was the most interesting country for emigrants, since 2014 most Slovaks have emigrated to work in Austria. Until 2016, 
most emigrants were in the age category of 25-34 years, since 2017, most workers emigrated in the age group of 35-44 years. We analyze in which sectors emigrants from Slovakia work in Figure 1.

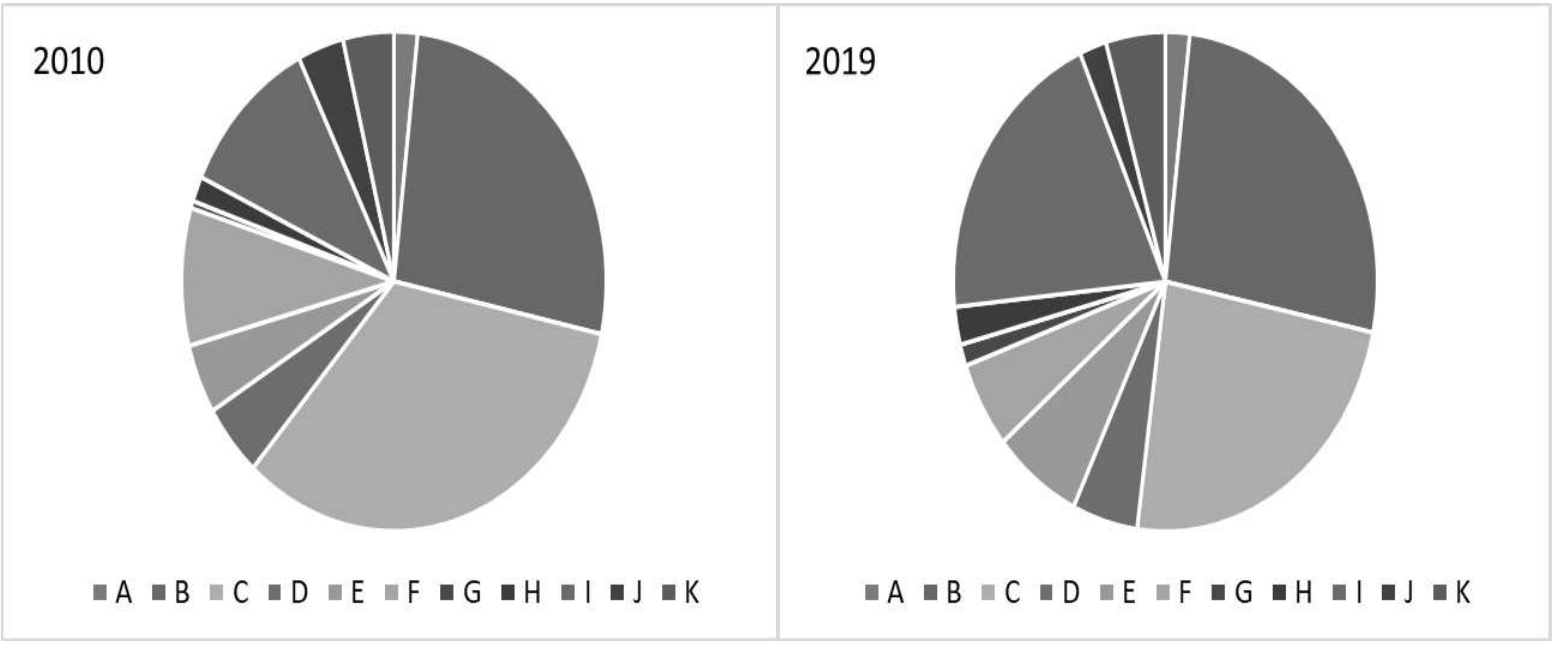

Notes: A- Agriculture, B - Industry, C - Construction, D - Wholesale, retail trade, E -Transportiation, storage, F Accommodacion, food services, $\mathrm{G}$ - Information, Communication, $\mathrm{H}$ - Science anf technical activities, I -Health, J Activities of households, $\mathrm{K}$ - Others

Fig. 1. Number of emigrants from Slovak Republic in sectors

Most emigrants worked in the Contruction sector in $2010(33 \%)$, followed by the Industry sector (27\%) and the Health sector in third place (11\%). In 2019, most emigrants worked in the Industry sector $(26 \%)$, followed by the Construction sector $(24 \%)$ and the third was the Health sector (with 20\% emigrant workers).
The health sector was the sector in which the number of emigrants increased the most during our period under review. The development of emigrant workers in the health sector is demonstrated in Figure 2.

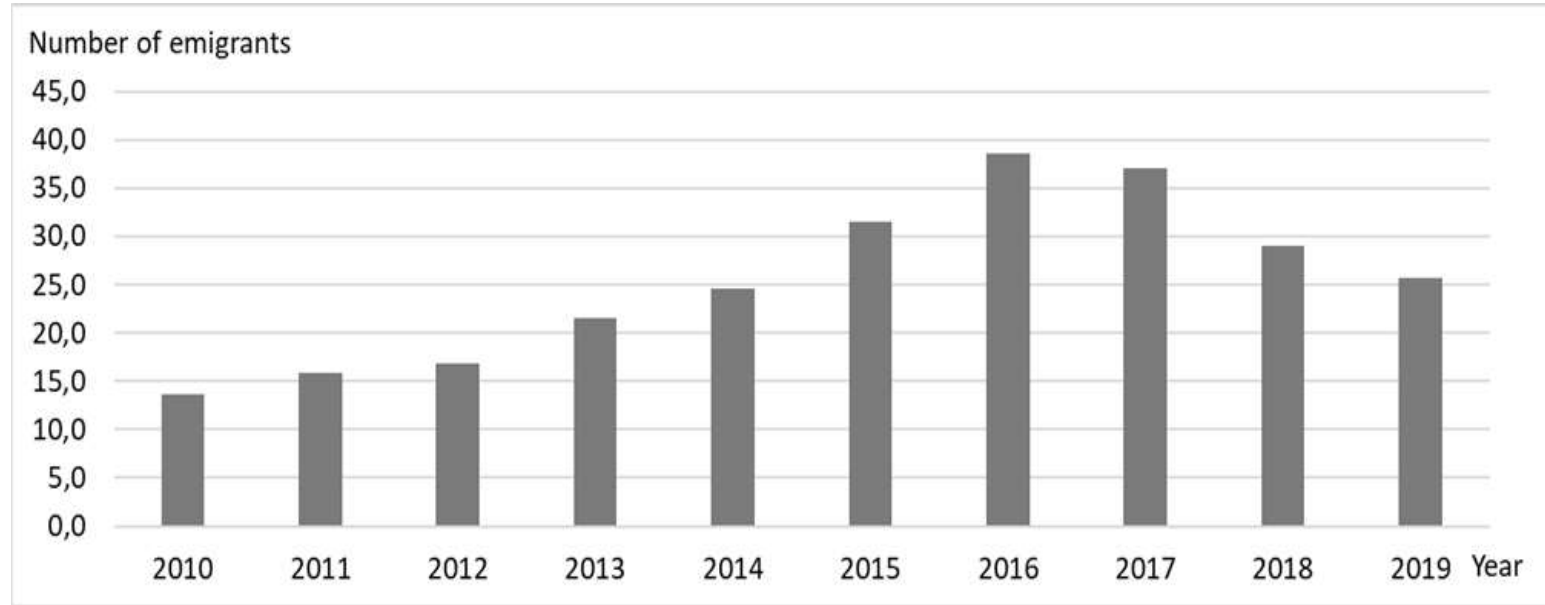

Fig. 2. Number of emigrants from Slovak Republic in health sector

Although the number of emigrants for work in the health sector has been declining in the last three years, in 2019 more than 12,000 more emigrants worked in this sector than in 2010. In 2016, more than 38,700 people worked abroad in the health sector.

The reasons for the migration of health professionals are various. This can be a higher salary, abroad, better working conditions abroad, including better equipment for hospitals and clinics, as well as the reason can be failure to enter the domestic labor market. To identify what effect the migration of health care workers may have on the number of health professionals in the Slovak Republic, it is first necessary to analyze the number of workers in the health care sector in the Slovak Republic.

The average number of people working in the health sector over the last 10 years can be seen in Figure 3 .

Of the total post employed in the economy of the Slovak Republic, an average of $7.2 \%$ of employees worked in the healthcare sector in 10 years. The number 
of employees increased by more than 28,000 from the beginning to the end of the observed period.

During the observed period, the number of working women was several times higher than the number of working men. The average share of men for the whole monitored period was at the level of $15.8 \%$, which means that the share of women was on average $84.2 \%$ in the monitored period.
Although the increase is marked, the number of job vacancies in this sector has been increasing in the last three years. In the last three years, more than a thousand jobs have been vacant in the healthcare sector. Although the number of job vacancies in this sector is growing with a link to labor migration, these vacancies could be easily filled.

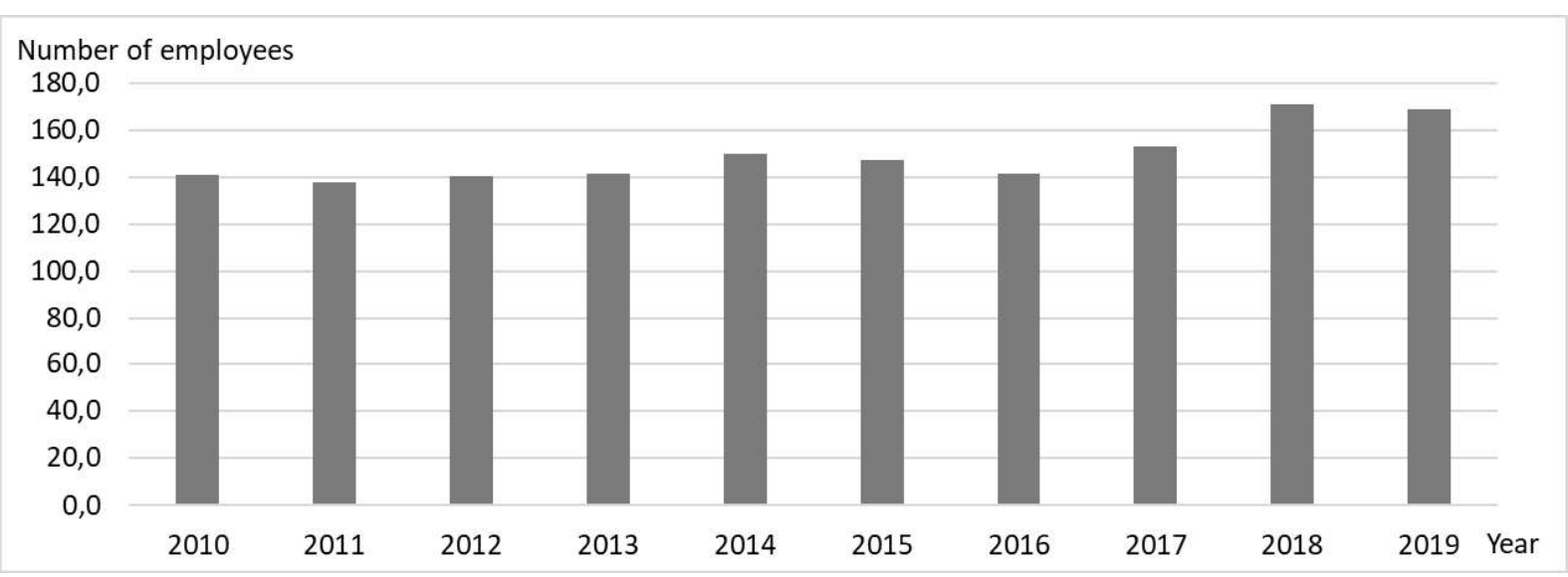

Fig. 3. Number of employees in the health sector

After identifying the emigration of the Slovak labor force in the health sector abroad and after analyzing the number of workers in the health sector in Slovakia, we now identify the impact of the mentioned emigration on the labor force in Slovakia.

We used the method of regression and correlation analysis to calculate the dependencies. The value of the number of workers in the health sector in the Slovak Republic was set as a dependent variable, and the value of the number of emigrants from the Slovak Republic abroad was set as an independent variable. The result of the regression and correlation analysis is shown in Figure 4.

Based on the calculations, a simple linear model was identified as the most suitable model. The correlation coefficient has a value of 0.8886 , which means that there is a high dependence between the investigated phenomena. The coefficient of determination, which has a value of 0.6742 , means that the model used explains $67 \%$ of the total variability of the examined data. The value of Significance $F$ is less than $\alpha=0.05$, therefore the regression model can be considered suitable for describing the investigated dependence.

\begin{tabular}{lr}
\hline \multicolumn{2}{c}{ Regression Statistics } \\
\hline Multiple R & 0,888594322 \\
R Square & 0,67416214 \\
Adjusted R Square & 0,323922751 \\
Standard Error & 9,809332032 \\
Observations & 10 \\
\hline
\end{tabular}

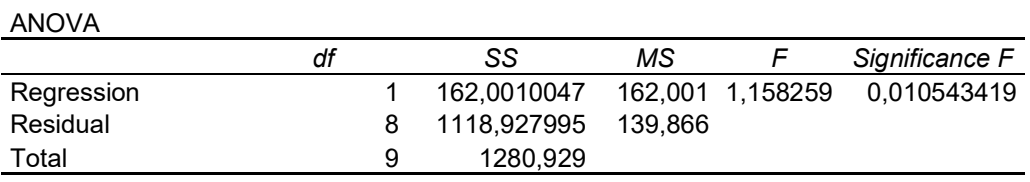

\begin{tabular}{lrrrrrrrr}
\hline & Coefficients & Standard Error & \multicolumn{1}{c}{$t$ Stat } & P-value & \multicolumn{1}{l}{ Lower 95\% } & \multicolumn{1}{c}{ Upper 95\% } & Lower 95,0\% & Upper 95,0\% \\
\hline Intercept & 136,7631396 & 12,13727102 & 11,26803 & $3,46 \mathrm{E}-06$ & 108,7745424 & 164,7517367 & 108,7745424 & 164,7517367 \\
X Variable 1 & $-0,48818937$ & 0,453613051 & 1,076224 & 0,031321 & $-0,557844201$ & $-0,134222942$ & $-0,557844201$ & $-0,134222942$ \\
\hline
\end{tabular}

Fig. 4. The result of the regression and correlation analysis

The regression function has the form $y=136.763$ $0.48819 \mathrm{x}$. The value of Intercept - b0 = 136,763 indicates that if migration were zero, the number of jobs in Slovakia would be more than 136 thousand. The value b1 $=-0.48819$ says that if migration increases by one unit of measure (ie by one person), then the number of workers in Slovakia in the health sector will decrease by 0.48819 . Also from the above calculations we can say with $95 \%$ probability that if the migration increases by 
one unit of measure, the number of workers in Slovakia will decrease from -0.5578 to -0.1342 .

\section{Conclusion}

The main goal of the presented study was to analyze trends in labor migration as a whole in the Slovak Republic, identify the share of emigration of health workers from the Slovak Republic abroad and identify whether the migration of health workers will affect the decline in health care in the Slovak Republic. The Slovak Republic is a country where the number of emigrant workers has increased in the last decade. Preferences within the most interesting country for migrants have changed over the decades.

While at the beginning of the period under review the Czech Republic was the most interesting country for emigrants, since 2014 most Slovaks have emigrated to work in Austria. Slovaks emigrated the most for work in the Contruction sector, Industry sector and Health sector. The health sector was the sector in which the number of emigrants increased the most during our period under review. Although the number of emigrants for work in the health sector has been declining in the last three years, in 2019 more than 12,000 more emigrants worked in this sector than in 2010.

As we met the goal of research, whether the changing number emigrants in the health sector from the Slovak Republic, will affect the number of employees in the health sector in the Slovak Republic, we also analyzed the number of employees in the health sector in the Slovak Republic. In 10 years, the number of workers in the healthcare sector in the Slovak Republic has been increasing. The number of employees increased by more than 28,000 from the beginning to the end of the observed period. Although the increase is marked, the number of job vacancies in this sector has been increasing in the last three years. In the last three years, more than a thousand jobs have been vacant in the healthcare sector.

After connecting all the examined parts, we can say that the migration of the medical workforce affects the number of employees in the health sector in Slovakia. With the growing number of vacancies in the health sector in Slovakia, the growing emigration of labor in this sector may exacerbate the shortage of health workers. With the current situation of the ongoing Covid-19 infection, where health workers are in great need and with an aging population, the health sector in the Slovak Republic will be considered, in the opinion of the authors, as the most endangered sector in terms of labor shortages.

This paper can serve as a basis for further scientific research in the context of labor emigration and also as a basis for addressing the issue of examining the causes and effects of migration of doctors and nurses to work abroad.

\section{Acknowledgment}

„This work was supported by the Slovak Research and Development Agency under the contract No. APVV19-0579."

\section{References}

BACH, S. 2003. International migration of health workers: labour and social issues. Geneva: Sectoral Activities Programme, International Labour Office. [online]. [cit. 2020-09-10]. Available on: https://www.hrhresourcecenter.org/node/154.html

BRADBY, H. 2014. International medical migration: A critical conceptual review of the global movements of doctors and nurses. In Health. 18(6). pp. 580-596. ISSN 1363-4593.

COLOMBIER, C. 2018. Population ageing in healthcare - a minor issue? Evidence from Switzerland. In Applied Economics. 50(15). Pp. 1746-1760. ISSN 0003-6846.

DIVINSKÝ, B. 2009. Migračné trendy v Slovenskej republike po vstupe krajiny do EÚ (2004-2008). Bratislava: IOM. 118 p. ISBN 978-80-970274-2-1.

DOBRIANSKY, P. J., SUZMAN, R. M., HODES, R. J. 2007. Why Population Aging Matters. In A Global Perspective. National Institute on Ageing, National Institute of Health, $32 \mathrm{p}$.

HANÁK, R. 2016. Dátová analýza pre sociálne vedy. Bratislava: Ekonóm. 1. vyd. 148 p. ISBN 978-80-225-43453

JAKOVLJEVIĆ, M. 2017. Population ageing alongside health care spending growth. In Serbian archives of medicine. 145(9-10). pp. 534-539. ISSN 0370-8179.

JAYAWARDANA, S., CYLUS, J., MOSSIALOS, E. 2019. It's not ageing, stupid: why population ageing won't bankrupt health systems. In European Heart Journal - Quality of Care and Clinical Outcomes. 5(3). pp. 195-201.

KANE A. 2012. Flows of medicine, healers, health professionals, and patients between home and host countries. In: Medicine, mobility, and power in global Africa: transnational health and healing. Bloomington: Indiana University Press. pp. 190 - 212. ISBN 978-0-25300532-8

KRAJŇÁKOVÁ, E., VOJTOVIČ, S. 2017. Struggles of older workers at the labour market. In Economics \& Sociology, 10 (1). ISSN 2071-789X, pp. 319-333.

LANARI, D., BUSSINI, O., MINELLI, L. 2018. The Effects of Immigrant Status and Age at Migration on Changes in Older Europeans' Health. In International Migration Review, 52 (4). ISSN 0197-9183, pp. 1218-1249.

LISENKOVA, K., MÉRETTE, M., WRIGHT, R. 2013. Population ageing and the labour market: Modelling size and age-specific effects. In Economic Modelling, vol. 35, pp. 981-989. ISSN 0264-9993

NAVICKAS, V., KONTAUTIENE, R. 2013. The interaction between corporate social responsibility and competitiveness during the economic downturn. In Economics and Management, 18 (1). pp. 58-67. ISSN 2029-9338.

PALKOVIČ. 2014. Štatistika B. [online]. [cit. 2020-09-10]. Available

on: https://spu.fem.uniag.sk/cvicenia/ksov/palkovic/statistikaB/ prednasky/8.Regresn $\%$ c3\%a1\%20a\%20korela $\%$ c4\% $\%$ dn $\%$ c $3 \%$ a $1 \% 20$ anal $\%$ c3\%bdza.pdf

RIEVAJOVÁ, E., PONGRÁCZ, E., KLIMKO, R. 2016. Trh práce a politika zamestnanosti. Bratislava: Ekonóm. 261 p. ISBN 978-80-225-4356-9.

SILVA, K. L., et. al. 2016. Migrant nurses in Brazil: demographic characteristics, migration flow and relationship with the training process. In Revista LatinoAmericana de Enfermagem. 4:e2686. [online]. [cit. 202009-10]. Available from: 
https://www.researchgate.net/publication/330890491 Brazil ian_nurses'_sociodemographic_changes_in_the_first_decad e_of the 21 st_century [accessed Oct 12 2020].

STARTIENE, G., REMEIKIENE, R. 2009. The Influence of Demographical Factors on the Interaction between Entrepreneurship and Unemployment. In Inzinerine Ekonomika-Engineering Economics (4), ISSN. 1392-2785. pp. 60-70.

STATISTICAL OFFICE OF THE SLOVAK REPUBLIC. Database DataCube. 2020. online]. [cit. 2020-09-10]. Available on: http://datacube.statistics.sk/\#!/lang/en

STATISTICAL OFFICE OF THE SLOVAK REPUBLIC. Quarterly statistical documents Labour force sample survey 2010 - 2017. [online]. [cit. 2020-09-10]. Available on: https://slovak.statistics.sk/

TRIANDAFYLLIDOU, A. 2018. Handbook of migration and globalisation. United Kingdom: Cheltenham. 487 p. ISBN 978-1-78536-750-2.

TUPÁ, M. 2016. Consequences of labour migration and migration management for example of Slovak Republic. In
Proceedings of the 1st international conference contemporary issues in theory and practice of management: CITPM 2016. Czestochowa: Wydawnictvo Wydzialu Zarzadzania Politechniki Czestochowskiej, pp. 445-450. ISBN 978-83-65179-43-2

TUPÁ, M. 2020. Staffing in Slovak's health care in the context of qualified nurses emigration. In Zdravotnícke listy. 8(1). pp. 38-46. ISSN 2644-4909.

TUPÁ, M., KRAJČO, K. 2019. Immigration of physicians to Slovakia - case study. In Problems and Perspectives in Management. 17(4). pp. 262-273. ISSN 1727-7051.

VOJTOVIČ, S. 2013. The impact of Emigration on Unemployment in Slovakia. In Inzinerine Ekonomika Engineering Economics, 24 (3). ISSN 1392-2785. pp. 207216.

WOJCZEWSKI, S. et al. 2015. Diaspora engagement of African migrant health workers - examples from five destination countries. In Global Health Action. 8 (1). ISSN 1654-9716.

\section{Simona Hyžová}

She graduated from the Department of Human Resources and Personnel Management at the Alexander Dubček University of Trenčín in Trenčín. She currently works as a doctoral student at the Department of Management and Human Resources Development at the Faculty of Socio-Economic Relations of the Alexander Dubček University of Trenčín in Trenčín, where she is studying the Department of Human Resources and Personnel Management. Her scientific focus focuses on the issue of wage differentiation in the Slovak Republic in the context of the situation on the labor market. During her studies, she participated in a cross-border cooperation program focused on V4 "Corporate social responsibility Academy in V4 - Universities for society." She is currently involved in a project aimed at setting up personnel management processes in hospitals and its impact on the migration of doctors and nurses to work abroad and in a project focusing on the digital economy and changes in the education system as a reflection on labor market requirements. Department of Management and Human Resource Development, Faculty of Social and Economic Relations, Alexander Dubček University of Trenčín, Študentská 3, 91150 Trenčín, Slovakia, phone: +421327400450 simona.hyzova@tnuni.sk 